these, entitled "Steel for A.R.P.", suggests ways in which standardized steel products can be used for air-raid protection. One of these standard products is corrugated steel sheets and it can be used for overhead cover. Similarly the steel arches used to support the roadways of collieries are applicable to construct shelters in basements, railway embankments and cuttings. The booklet dwells on the advantages of steel frame construction from the point of view of its ability to resist explosive shock. These frames withstand stresses in any direction. A frame is not dependent for its strength upon the walls, and it can easily be repaired. Various types of wall and floor construction are described and so also are the customary brick panels. The latter are considered to be able to deal with blast and splinters when well tied up to the supporting structure. The use of pressed-steel window sub-frames can increase their strength. In existing buildings the most appropriate site for a shelter is the basement, and some useful hints are given of the best way of using existing steel products to strengthen it. The second book deals with the "Everyman" trench shelter, and will be of interest to many. It describes with the help of drawings how a householder can build a shelter capable of holding four persons and sufficient to afford protection against blast and splinters. For the roof curved sheets five feet long are used and standard flat corrugated iron sheets six feet long for lining the walls. A bill of the quantities required is given. It has been suggested that now that time is not important, there will be many who will consider it worth while to build such a shelter in their leisure hours. As the roof will be covered with the excavated. soil, it might be sown or planted in such a way that the amenities of the garden would not greatly suffer.

\section{Protecting Airships Against Fire}

Some of the problems that have to be solved when protecting airships against fire, due to electric sparks in the neighbourhood of free hydrogen, are discussed in an article in The Times of October 18. The latest German airship, the LZ 130, which inherits the name of Graf Zeppelin, is denied the use of helium, and so uses hydrogen gas. Dr. Hugo Eckener and his colleagues are engaged in experiments during flight to test a project for making the potential of the static electricity within the airship frame equal to that of the electrical field outside. The experiments are based on the use of a new instrument which records the nature and intensity of the static charge in the airship and of the electrical conditions in the atmosphere surrounding the hull. Its function appears to be that of warning the captain of conditions in which it would be dangerous to 'valve' gas or to have an appreciable leak of gas. There is little danger even when the aircraft passes through a field of opposite charge, unless there is a gap in the bonded structure across which a spark may jump. If the new instrument works satisfactorily, it would give a warning when the conditions were dangerous and special precautions could be taken. It would enable the captain to see whether or not it was desirable to earth a positive charge when in the neighbourhood of a negatively charged cloud. Such stations have been made in miniature and experiments on a small scale have been carried out. Experiments will shortly be made in full scale under natural conditions.

\section{Excavation of a Neolithic Barrow in Kent}

SIR EDMUND DAvis's excavation of Julaber's Grave, Chilham Hill, Kent, under the direction of Mr. R. F. Jesup, in continuation of the investigations of 1937, after a brief interruption during the recent crisis, owing to the absence of the director, has been brought to a close, after being carried to a point at which it was proved conclusively that the barrow is of neolithic age. Reports of the result of the excavation (The Times, October 1 and 12), state that a polished flint axe, about six inches long, with flattened sides, curved edge, and made of creamy white flint, was found in a layer at a depth of four feet six inches, in which were also rough sherds, a human tooth, pointing to a burial, and a number of flint flakes, such as are found only in the area of the mound in the adjacent cultivated soil. Traces of charcoal in the core of the mound, particularly in the neolithic turf layer, support the theory that the area was cleared by burning. The polished flint axe, which substantiates the neolithic dating of the mound, is of Scandinavian type, and, it is suggested, allies the mound with the megalith builders of the Baltic, rather than with the long barrow peoples of Dorset and Wiltshire. It is certainly significant that, as the report points out, Julaber's Grave, in relation to the other long barrows of Britain, stands in a position of isolation. Further investigation of the Roman burial containing the skeletal remains of three individuals, which was found in 1937, has revealed a remarkable, and at first sight puzzling, construction of flint at the southern end of the grave. This has proved to cover the burial of a man and a horse. The head of the horse, however, is missing, and the usual platter and bowl are in fragments. Apparently the burial had been disturbed; while the flint structure had been placed there to prevent the remains, buried in the side of the mound, from slipping into the ditch.

\section{Reduction of Maternal Mortality}

THE Minister of Health has communicated with local supervising authorities on methods that may be adopted in order to secure that the best obstetric aid is available to expectant mothers on occasions when midwives have to call in a doctor (Ministry of Health Circular 1705. H.M. Stationery Office. $1 d$. net). The recommendations are that a panel of doctors who will be available for this service should be drawn up for the area of each authority, and that a small advisory committee should be set up to advise the authority in regard to the operation of the arrangements and on any alteration that may be deemed necessary in order to secure and maintain a high standard of obstetric practice. It is hoped that the adoption of arrangements on these lines will help in reducing the present maternal mortality rate. 